ÊXODO. Trad. Ludovico Garmus. Introdução de David Grossman. Tradução da introdução de José Antônio Arantes. Rio de Janeiro: Objetiva, 1999. 120p.

\title{
Notas sobre uma introdução
}

\section{Márcio César Pereira *}

O ano de 1998 marca o cinquentenário da fundação de Israel, o moderno está judeu. Seguiram-se, a essa data, publicações, filmes e eventos diversos relacionados direta e indiretamente com a comemoração. No Brasil, foi lançada pela editora Objetiva uma pequena coletânea em doze volumes denominada "Os Livros da Bíblia" com edições prefaciadas por diferentes personalidades da cultura, entre elas, o escritor israelense David Grossman, encarregado de fazer a introdução ao livro de "êxodo".

David Grossman faz parte da primeira grande geração de escritores nascidos em Israel, pósunificação, cujos trabalhos refletem sua condição nativa de cidadão de Israel, nação reconhecida com fronteiras estabelecidas e localizadas no tempo e no espaço contemporâneo. Grossman é, portanto, um escritor de um país real que, ao avaliar um texto fundador, que é a Bíblia, estabelece, nele, as premissas da criação de seu povo. Talvez por isso, sua reflexão se detenha nos efeitos da formação da identidade judaica.

O êxodo, segundo volume do Pentateuco, é denominado pela palavra hebraica shemot, nomes, de acordo com suas primeiras palavras: "Eis os nomes...". A palavra grega exodo, pretende resumir a essência da obra, a saber: a história da libertação do povo hebreu, escravizado no Egito, sua libertação por Moisés, suas errâncias no deserto e seu pacto com Deus.

David Grossman ignora, de certa forma, Moises, esse grande líder, cuja história é detalhada nos primeiros capítulos do êxodo. Ao contrário, ele descreve como uma "outra história mais pungente e pessoal". Tão pouco se detém nas passagens maravilhosas como a da sarça ardente ou a das famosas pragas, para ele, "uma tessitura quase ilusória de contos de fada com um severo código legal e religioso."Mesmo reconhecendo a estrutura que sustenta o livro, a fabulação é relativizada e emerge, na introdução de Grossman, outro personagem, o povo escravizado, retirado do Egito e impelido para o deserto e para o seu desconhecido e incerto destino.

Confusão, estranhamento e, sobretudo, temor, assomariam, para o escritor, o povo hebreu no deserto. Para Grossman, ele se encontraria perdido entre o passado de escravidão, física e espiritual, e futuro que se apresenta como incerto. Ele não conhece seu libertador, um estranho que foi criado como um príncipe egípcio e depois viveu como pastor na longínqua Madiã. Tampouco conhecem o Deus caprichoso que os libertou e os alimenta no deserto, um Deus temerário, lembra Grossman, pois "viram como Ele lidara com os egípcios, sabem como Ele pode ser imprevisível, brutal e feroz." Mudanças drásticas e repentinas teriam, desse modo, forjado, naquela população, a dúvida e a rebelião. A chamada "geração do deserto" é, pois, condenada a extinção.

É comovente como o escritor se compadece daquela geração, lembrada por ele como a "geração do conhecimento", pois, como diz o Zohar, esta teria "testemunhado os extraordinários feitos de Deus". A identidade do povo judeu teria, assim, sido forjada nos quarenta anos de peregrinação dos hebreus no deserto. Um povo marcado por esse constante mover, ou como afirma Grossman: "O povo de Israel formou-se como resultado de um mandamento para perambular até um novo lugar".

Tal identidade teria sido forjada, portanto, sobre um paradoxo, o ímpeto de perambular e a nostalgia de um lugar. Para Grossman, essas duas forças geraram no povo hebreu sua grande força para 
renascer e continuar, e, também, sua propensão para a vitimização e a tragédia. Israel mudou a visão histórica do divino, por conseqüência, da natureza. Seu Deus invisível e único, sua errância eterna em busca de uma promessa, sua capacidade de crescer e se reinventar, tornaram tornou-se um enigma tanto para si quanto para os outros povos, diante de uma difícil definição matizada em uma questão cíclica: afinal o que é um judeu? O povo da promessa, o povo de Deus ou o povo escravo de uma metáfora perene?

Grossman lê o êxodo em seu escritório em Jerusalém e se pergunta como é possível que, mesmo hoje, e mesmo por seus habitantes, Israel ainda seja chamado de a "terra prometida". Ou seja, mesmo naquela data, cinquenta anos passados da formação do estado judeu, seu país ainda está preso ao estigma da "promessa eterna" ou como ele mesmo afirma, à "maldição do eterno", que paria sobre a identidade e o destino daquela população.

O livro do êxodo é o épico da "grandiosa historiada infância do povo judaico", mas é, também, o pórtico da face que permanecerá sobre a identidade judaico ainda por milhares de anos. Grossman ao apresentar esse antigo texto, revela como uma história pode ser gregária ao destino daqueles que a construíram, uma prisão tão forte como aquilo que chamamos de realidade.

* Márcio César Pereira é Graduado em Letras pela Universidade Federal de Minas Gerais. 